be of significance in the accelerated growth of turtles. These turtles withstand maintained centrifugation much better than do mice of comparable size. Perhaps such factors as buoyancy, shell, and lower body temperature protect the turtle from the deleterious results which have been demonstrated for mice and certain other warmblooded animals. If this were so, the net developmental acceleration would accordingly be more pronounced.

This work was supported in part with National Institutes of Health grants Nos. $G M-K 3-4756$ and $R G-8728$. Christopher H. Dodge

Department of Physiology, Charles C. Wunder

State University of Iowa, Iowa City, Iowa.

'Gray, S. W., and Edwards, B. F., J. Cell. and Comp. Physiol., 46, 97 (1955).

${ }^{2}$ Wunder, C. C., Herrin, W. F., and Crawford, C. R., Growth, 28, 349 (1959). ${ }^{3}$ Wunder, C. C., Briney, S. R., Kral, M., and Skaugstad, C., Nature, 188, $151(1960)$.

- Thompson, D'A. W., On Growth and Form, second ed,, 22, 194, 958 (Cambridge Univ.'Press, 1942).

\section{Long-Distance Migration of Salmon}

IT was reported recently ${ }^{1}$ that a salmon tagged as a smolt in the estuary of the River Usk in Monmouthshire was caught some eighteen months later near Sukkertoppen on the west coast of Greenland.

Information has now been received that in October, 1962, another English salmon was caught in the same area. This fish was tagged as a smolt in the River Wye at Brockhampton, near Hereford, on April 5, 1961.

Freshwater Fisheries Laboratory,

A. SWAIN

Ministry of Agriculture, Fisheries and Food,

Whitehall Place, London, S.W.1.

'Swain, A., Hartley, W. G., and Davies, R. B., Nature, 195, 1122 (1962).

\section{ENTOMOLOGY}

\section{Insects attacking Striga in Kenya}

WiLliams and Caswell ${ }^{1}$ have reported Smicronyx sp. (Curculionidae; Coleoptera) attacking Striga sp. in Nigeria. Murthy ${ }^{2}$ has given an account of the attack of Smicronyx albovariegatus Faust. on Striga in India and has listed other insect pests of Striga in that country.

Striga hermonthica Benth. (Scrophulariaceae) is an important root parasite of sorghum, the principal cereal crop of the low-lying areas near Lake Victoria in Nyanza Province, Kenya. Maize and wild grasses are also attacked. In 1960 and 1962 Striga plants were examined for insect damage. In both years the commonest pest was found to be a small agromyzid fly, which has been identified as a new species, Ophiomyia strigalis Spencer ${ }^{3}$. Attack commences when Striga begins to flower in late June; and by the beginning of August more than 90 per cent of plants have been attacked. The eggs are inserted singly into the soft epidermis in the axils of leaves 1-1.5 in. above soil-level. The larva makes a narrow mine, stained purplish-black, just underneath the epidermis. The mine goes almost straight downwards to below soil-leve], where it then pursues a more tortuous course under the epidermis of the root to a depth of 3-4 in. The mature larva returns up the mine and pupates at soil-level where the site of the puparium can be detected as a small blister of the epidermis. Up to 10 puparia have been found in a single plant; the mean number found in August 1962 was 2 puparia per plant. The maximum interval which has been observed between the caging of infested Striga material and the emergence of adult flies is 25 days. Attack causes the root epidermis to rot and peel off, and reduces the number of lateral roots, but no debilitation of the aerial parts of the plant, or reduction of numbers of flowers or fruits has been observed.
O. strigalis is attacked by a number of hymenopterous parasites. In 1960 a collection of infested Striga material yielded 220 . strigalis, 26 Eucoilidea sp. (Cynipoidea), 2 Opius liogaster Szepl. (Braconidas) and 2 Herberia sp. (Pteromalidae). In 1962 the incidence of these parasites was lower. Some $O$. strigalis eggs have been found to contain Hymenopterous pupæ.

In 1960 about 10 per cent of Striga plants at Kibos were found to bear one to three stem galls, usually on the main stem about 3 in. above soil-Jevel. The primary gallformer appeared to be a Eurytoma sp. (Eurytomidae; Hymenoptera). Other insects obtained from the galls were a cecidomyid (Cecidomyidae; Diptera) the larvæ of which appeared to feed on fungus in the cavities of the galls a Bracon sp. (Braconidae; Hymenoptera) and a Ceraphron sp. (Ceraphronidae; Hymenoptera).

Gall-bearing plants had fewer mature fruit than noninfested plants, but it could not be determined whether this was an effect of attack or whether only late-maturing plants were attacked. Only one galled plant has been found in 1962.

Le Pelley records Platyptilia taprobanes Fldr. and Stenoptilia zophodactyla Dup. (Pterophoridae; Lepidoptera) from Striga in Tanganyika. No Smicronyx sp. have been found on Striga in Kenya.

I thank the Director, Commonwealth Institute of Entomology, for identifying the insect species concerned, and the Director of Agriculture, Kenya, for permission to publish this communication.

Department of Agriculture,

Cotton Experiment Station, P.O. Kibos,

Kenya.

'Williams, C. N., and Caswell, G. H., Nature, 184, 1668 (1959).

${ }^{2}$ Murthy, D. V., Nature, 187, 959 (1960)

spencer, K. A., J. Entomol. Soc. South Afr. (in the press).

- Le Pelley, R. H., Agricultural Insects of East Africa (Nairobi, 1959).

\section{Effect of Synthetic 'Queen Substance' (9-oxodec-trans-2-enoic acid) on Ovary Development of the House-fly, Musca domestica $L$.}

RECENT investigations' have shown that when 'queen substance' (9-oxodec-trans-2-enoic acid) is distributed throughout the colony of honey bees, it partially inhibits the development of ovaries in workers and influences their behaviour by inhibiting queen-cell construction. Similar effects of crude extracts of queen honey bees have been demonstrated on other groups of social insects, for example, Formica fusca L. ${ }^{2}$ and Kalotermes flavicollis $\mathbf{F} .{ }^{3}$ This non-specificity for orders of social insects suggests that 'queen substance' might have similar inhibitory effects on ovary development even of non-social insects. This hypothesis was tested by examining the effect of synthetic 'queen substance' on ovary development in the house-fly, Musca domestica L.

In the house-fly the ovaries of newly emerged virgin females are undeveloped (Table 1) and female flies require a protein diet such as milk for egg development. When newly emerged female flies were 6-8 h old, samples of twenty flies each were injected in the thorax with $5 \mu l$. per fly of a $2 \mathrm{mg} / \mathrm{ml}$. of dilute ethanolic solution of synthetic 'queen substance' with a $50 \mu \mathrm{l}$. Hamilton micro-syringe, and injections were repeated at the time-intervals shown in Table 1. Higher-concentrations of synthetic 'queen substance' were found to be toxic and lower concentrations did not show any appreciable effect on the inhibition of ovary development in the house-fly. The treated and control flies were allowed to feed on a $1: 1(\mathrm{v} / \mathrm{v})$ mixture of condensed milk and water, replenished daily, for a total period of $96 \mathrm{~h}$. Then the flies were disseeted and their ovaries measured. 